\title{
LITERASI DIGITAL: TINGKAT DAN KEANDALAN SUMBER REFERENSI MAHASISWA DALAM MENULIS ESAI AKADEMIK
}

\author{
Abdul Haliq ${ }^{1}$, Akmal Hamsa ${ }^{2}$ \\ ${ }^{1,2}$ Universitas Negeri Makassar, Sulawesi Selatan, Indonesia. \\ Abdul.haliq@unm.ac.id ${ }^{1}$, akmalhamsa@unm.ac.id ${ }^{2}$
}

\begin{abstract}
This study aims to describe the level of digital literacy and the reliability of reference sources for student academic essays. The research uses a quantitative approach with quantitative descriptive research. This research was conducted on 32 students of the UNM Language and Literature Education Study Program which were obtained using purposive sampling technique. Collecting data using questionnaires, documentation, and interviews. The data analysis technique used quantitative descriptive analysis using presentation techniques. The results showed that the digital literacy level of students in general was in the very high category and the reference sources for student academic essays generally came from credible and trusted sources. This means that students have excellent digital literacy skills and are used in learning to write academic essays online by using various technological devices and applications on the internet that support the learning process
\end{abstract}

Keywords: academic essays; realibility of sources; digital literacy.

\begin{abstract}
ABSTRAK
Penelitian ini bertujuan untuk mendeskripsikan tingkat literasi digital dan keandalan sumber referensi esai akademik mahasiswa. Penelitian menggunakan pendekatan kuantitatif dengan jenis penelitian deskriptif kuantitatif. Penelitian ini dilakukan pada mahasiswa Program Studi Pendidikan Bahasa dan Sastra UNM yang berjumlah 32 orang yang diperoleh dengan menggunakan teknik purposive sampling. Pengumpulan data menggunakan teknik angket, dokumentasi, dan wawancara. Teknik analisis data menggunakan analisis deskriptif kuantitatif menggunakan teknik presentasi. Hasil penelitian menunjukkan bahwa tingkat literasi digital mahasiswa pada umumnya berada pada kategori sangat tinggi dan sumber referensi esai akademik mahasiswa pada umumnya berasal dari sumber yang kredibel dan terpercaya. Hal ini berarti mahasiswa memiliki keterampilan literasi digital yang sangat baik dan digunakan dalam pembelajaran menulis esai akademik secara daring dengan penggunaan berbagai perangkat teknologi dan aplikasi-aplikasi di internet yang mendukung proses pembelajaran.
\end{abstract}

Kata kunci: esai akademik; keandalan sumber; literasi digital.

\section{PENDAHULUAN}

Kebijakan pembelajaran daring pada masa pandemic covid-19 dilakukan melalui berbagai platfom yang tersedia di internet. Platform pembelajaran yang digunakan ada yang tersedia secara gratis dan ada pula yang dikembangkan oleh instusi masing-masing. Platform pembelajaran yang dikenal dengan istilah learning management system (LMS) merupakan pembelajaran yang dirancang melalui kelas virtual/online yang mencakup beberapa fitur seperti pendaftaran, kuis dan ujian, manajemen file tugas, dan sistem penilaiannya (Irhandayaningsih, 2020). LMS ini memungkinkan dosen dapat menyelenggarakan pembelajaran daring dengan berbagai dukungan media pembelajaran lain yang berbasis pada teknologi digital.

Pembelajaran daring atau virtual membuat mahasiswa dan dosen harus mahir dalam menggunakan perangkat teknologi digital. Kemampuan menggunakan teknologi digital ini juga merupakan bagian dari literasi digital. Kemampuan literasi digital merupakan kemampuan dalam 
menggunakan perangkat teknologi digital dan seringkali terlibat dalam mengakses atau menyebarkan informasi di dunia digital (Kirschner \& De Bruyckere, 2017). Istilah literasi digital juga mengacu pada praktik membaca, menulis, dan komunikasi yang dimungkinkan melalui media digital (Hafner et al., 2015). Untuk itu, dosen harus mampu berinovasi dalam pembelajaran guna menyajikan pembelajaran yang variatif dan memanfaatkan kemampuan literasi digital mahasiswa (Pretorius, 2018).

Inovasi pembelajaran daring dapat memanfaatkan keterampilan literasi digital mahasiswa dalam pembelajaran menulis akademik. Literasi digital menjadi pendekatan efektif digunakan dalam pembelajaran menulis akademik khususnya dalam mengevaluasi keandalan sumber referensi (Pretorius, 2018). Keandalan sumber referensi yang berupa referensi ilmiah menjadi salah satu syarat tulisan akademik. Referensi ilmiah seperti buku, artikel jurnal, hasil penelitian menjadi bagian dalam pengembangan tulisan akademik (Supriyanto \& Iswandari, 2017).

Pembelajaran menulis akademik dapat memanfaatkan berbagai sumber daya digital melalui pembelajaran daring untuk membantu mahasiswa dalam memperbaiki kualitas belajarnya. Sumber-sumber referensi atau informasi yang dibutuhkan dalam belajar tersedia secara gratis di internet dan dapat diakses kapan saja. Sumber-sumber referensi atau informasi ini dapat menjadi bahan dalam pembelajaran. Namun demikian, tidak semua referensi yang tersedia merupakan referensi yang dapat digunakan dalam pembelajaran, terutama dalam menulis akademik. Banyak ditemukan dalam tulisan ilmiah mahasiswa masih menggunakan berbagai referensi yang berasal dari sumber yang tidak valid atau tidak ilmiah. Hal ini berakibat pada rendahnya keandalan referensi tulisan ilmiah mahasiswa.

Untuk mengidentifikasi keandalan sumber referensi diperlukan dalam menulis ilmiah, kemampuan literasi digital yang baik dibutuhkan untuk menemukan, menganalisis, mengeva-luasi, dan menggunakan informasi atau referensi yang diperoleh dari internet (Bawden, 2008).
Tingkat kemampuan literasi digital mahasiswa berpengaruh terhadap kemampuan menulis ilmiah mahasiswa terutama dalam memilih sumber-sumber informasi kredibel dan relevan dengan kebutuhan tulisan ilmiah mahasiswa (Pretorius, 2018).

Beberapa penelitian telah dilakukan terkait literasi digital, di antaranya penelitian yang dilakukan oleh Irhandayaningsih, (2020) yang mengukur tingkat literasi digital mahasiswa pada pembelajaran daring. Hasil penelitian ini menunjukkan bahwa mahasiswa memiliki tingkat literasi digital yang tinggi berdasarkan aspek literasi digital Bawden. Selanjutnya, penelitian yang dilakukan oleh Buwono \& Dewantara, (2020) tentang hubungan media internet, membaca, dan menulis dalam literasi digital mahasiswa menunjukkan bahwa literasi digital mahasiswa yang ditunjukkan dalam perilaku literasi media internet sangat baik, literasi menulis mahasiswa sudah baik, namun pada literasi membaca masih belum baik. Adapun perbedaan dengan penelitian ini yaitu selain mengukur tingkat literasi digital mahasiswa, juga menunjukkan keandalan sumber referensi mahasiswa dalam menulis esai akademik. Penelusuran terhadap sumber referensi yang digunakan mahasiswa menjadi satu bentuk keterampilan literasi digital mahasiswa.

Penelitian ini bertujuan untuk mendeskripsikan tingkat literasi digital dan keandalan sumber referensi mahasiswa dalam tulisan esai akademik yang dikemas dalam pembelajaran daring selama pandemi Covid-19. Penelitian ini dilakukan pada mahasiswa yang memprogramkan mata kuliah Menulis Karya Ilmiah Program Studi Pendidikan Bahasa dan Sastra Indonesia, Fakultas Bahasa dan Sastra, Universitas Negeri Makassar.

Penelitian ini memiliki manfaat untuk secara teoritis mupun praktis. Secara teoritis penelitian ini bermanfaat untuk memberikan informasi tentang keandalan sumber referensi dan tingkat literasi digital mahasiswa dalam menulis akademik. Secara praktis, hasil penelitian ini dapat dijadikan sebagai landasan pemikiran bagi peneliti selanjutnya yang ingin meneliti tentang 
literasi digital dan hubungannya dengan menulis akademik.

\section{METODE PENELITIAN}

Penelitian ini menggunakan pendekatan kuantitatif dengan jenis penelitian dekriptif. Penelitian ini dilakukan pada mahasiswa Program Studi Pendidikan Bahasa dan Sastra Indonesia, Universitas Negeri Makassar. Populasi penelitian diperoleh dari mahasiswa yang terdaftar pada semester IV dan terdiri 3 kelas, yakni kelas 01, 02, dan 03. Pemilihan mahasiswa semester IV karena pada semester ini, mahasiswa mempro-gramkan mata kuliah Menulis Karya Ilmiah. Adapun yang dijadikan sampel pada penelitian yaitu kelas 03, dengan jumlah 32 orang mahasiswa. Pengambilan sampel menggunakan teknik purposive sampling.

Teknik pengumpulan data yang dilakukan adalah studi dokumentasi, penyebaran angket kepada responden terpilih, dan wawancara kepada pihakpihak tertentu yang dianggap memiliki informasi yang dibutuhkan untuk kepentingan penelitian. Peryataan angket digunakan untuk memperoleh data tingkat literasi digital mahasiswa dengan menggunakan skala likert. Studi dokumentasi digunakan untuk memperoleh data mengenai keandalan sumber referensi yang digunakan mahasiswa pada tulisan esai akademik. Data wawancara digunakan untuk mengonfirmasi hasil dari angket dan studi dokumentasi. Selanjutnya, data yang terkumpul dianalisis dengan menggunakan teknik deskriptif kuantitatif. Angket dianalisis dengan menghitung nilai rata-rata dan persentasi. Selanjutnya hasil persentasi diinterpretasikan dengan menggunakan tabel kategori berikut.

Tabel 1. Kriteria Interpretasi Skor Modifikasi Skala Likert

\begin{tabular}{|c|c|}
\hline Persentase (\%) & Kategori \\
\hline $0-20$ & Sangat Rendah \\
$21-40$ & Rendah \\
$41-60$ & Cukup \\
$61-80$ & Tinggi \\
$81-100$ & Sangat Tinggi \\
\hline
\end{tabular}

Sumber: Riduwan, 2008: 87-89.

Instrumen penelitian yang digunakan dalam penelitian ini yaitu berupa angket yang dikembangkan berdasarkan aspek literasi digital yang dikemukakan oleh Bawden, (2008) yang terdiri dari empat aspek utama yaitu kemampuan dasar literasi digital, latar belakang pengetahuan informasi, kompetensi utama, serta sikap dan perspektif. Angket yang digunakan sebelumnya telah dilakukan validasi dengan menggunakan jenis validasi ahli dengan keahlian di bidang pembelajaran teknologi informasi dan komunikasi. Angket telah dinyatakan valid dan dapat digunakan dalam pengambilan data.

Tabel 2. Aspek literasi digital oleh Bawden

\begin{tabular}{|c|c|c|}
\hline No. & Aspek & Indikator \\
\hline \multirow[t]{2}{*}{1.} & \multirow[t]{2}{*}{$\begin{array}{l}\text { Kompetensi Digital/ } \\
\text { keterampilan dasar }\end{array}$} & $\begin{array}{l}\text { Mahasiswa mengenali sumber daya digital yang } \\
\text { dibutuhkan. }\end{array}$ \\
\hline & & $\begin{array}{l}\text { Mahasiswa mampu menggunakan perangkat teknologi } \\
\text { sumber daya digital. }\end{array}$ \\
\hline \multirow[t]{3}{*}{2.} & \multirow{3}{*}{$\begin{array}{l}\text { Pengetahuan } \\
\text { mengenai latar } \\
\text { belakang informasi }\end{array}$} & Mahasiswa mampu mengenali jenis informasi. \\
\hline & & $\begin{array}{l}\text { Mahasiswa mampu mengenali sumber informasi yang } \\
\text { dibutuhkan. }\end{array}$ \\
\hline & & Mahasiswa mampu membedakan sumber informasi \\
\hline
\end{tabular}

Literasi Digital: Tingkat dan Keandalan Sumber Referensi Mahasiswa dalam Menulis Esai Akademik 


\begin{tabular}{|c|c|c|}
\hline & & yang valid dan tidak valid. \\
\hline \multirow[t]{9}{*}{3.} & \multirow[t]{9}{*}{ Keterampilan utama } & $\begin{array}{l}\text { Mahasiswa mampu menemukan konten atau informasi } \\
\text { yang dibutuhkan. }\end{array}$ \\
\hline & & $\begin{array}{l}\text { Mahasiswa mampu menggunakan kata kunci tertentu } \\
\text { untuk menemukan konten atau informasi yang } \\
\text { dibutuhkan. }\end{array}$ \\
\hline & & $\begin{array}{l}\text { Mahasiswa mampu menggunakan sumber daya digital } \\
\text { dalam penyelesaian masalah. }\end{array}$ \\
\hline & & $\begin{array}{l}\text { Mahasiswa mampu menilai dan menganalisis sumber } \\
\text { daya digital yang diakses.। }\end{array}$ \\
\hline & & $\begin{array}{l}\text { Mahasiswa mampu menyintesis sumber daya digital } \\
\text { yang diakses. }\end{array}$ \\
\hline & & $\begin{array}{l}\text { Mahasiswa mampu merefleksi hasil yang telah } \\
\text { diperoleh. }\end{array}$ \\
\hline & & $\begin{array}{l}\text { Mahasiswa mampu mengorganisasi, } \\
\text { mengintegrasikan, dan menghasilkan informasi atau } \\
\text { konten digital yang baru. }\end{array}$ \\
\hline & & $\begin{array}{l}\text { Mahasiswa mampu mengomunikasikan hasil kreasi } \\
\text { melalui pranala (website) edukasi. }\end{array}$ \\
\hline & & $\begin{array}{l}\text { Mahasiswa mampu berkomunikasi, berinteraksi, dan } \\
\text { berkolaborasi melalui pranala (website) edukasi. }\end{array}$ \\
\hline \multirow[t]{2}{*}{4.} & \multirow[t]{2}{*}{ Sikap dan perspektif } & $\begin{array}{l}\text { Mahasiswa mampu mengakses dan menilai konten } \\
\text { digital secara mandiri. }\end{array}$ \\
\hline & & $\begin{array}{l}\text { Mahasiswa mampu bertanggung jawab terhadap } \\
\text { informasi atau konten digital yang disebarkan. }\end{array}$ \\
\hline
\end{tabular}

\section{HASIL DAN PEMBAHASAN}

Tingkat literasi digital mahasiswa diukur menggunkan angket penelitian yang telah divalidasi oleh ahli pembelajaran teknologi informasi dan komunikasi (TIK). Angket penelitian dikembangkan menggunakan aspek literasi digital yang diusulkan oleh Bawden (2008) yang terdiri atas empat aspek, yaitu kompetensi digital, pengetahuan mengenai latar belakang informasi keterampilan utama, serta Sikap dan Perspektif. Adapun hasil penilaian tingkat literasi digital mahasiswa dapat dilihat pada tabel 3 berikut.

Tabel 3. Aspek Kompetensi Digital

\begin{tabular}{|c|lr|c|c|l|}
\hline No. & Indikator & Rata-rata & Persentasi & Kategori \\
\hline 1. & $\begin{array}{l}\text { Mahasiswa mengenali sumber daya } \\
\text { digital yang dibutuhkan. }\end{array}$ & 4.29 & $85.7 \%$ & Sangat tinggi \\
\hline 2. & $\begin{array}{l}\text { Mahasiswa mampu menggunakan } \\
\text { perangkat teknologi sumber daya } \\
\text { digital. }\end{array}$ & 4.08 & $81.67 \%$ & Sangat tinggi \\
\hline
\end{tabular}

Berdasarkan tabel 3 aspek kompetensi digital diukur menggunakan dua indikator. Indikator pertama yaitu mahasiswa mengenali sumber daya digital yang dibutuhkan dan memperoleh nilai ratarata 4.29 dengan persentasi $85.7 \%$ dan 
berada pada kategori sangat tinggi. Selanjutnya, indikator kedua yaitu mahasiswa mampu menggunakan perangkat teknologi sumber daya digital memperoleh nilai rata-rata 4.08 dengan persentasi $81.67 \%$ dengan kategori sangat tinggi. Berdasarkan hasil penilaian tersebut, diperoleh kesimpulan bahwa tingkat literasi digital mahasiswa pada aspek kompetensi digital berada pada kategori sangat tinggi. Hal ini berarti mahasiswa pada umumnya mahasiswa memiliki kompetensi digital untuk menggunakan dan mengakses sumber daya digital yang dibutuhkan selama proses pembelajaran menulis esai akademik.

Tabel 4. Aspek Pengetahuan Mengenai Latar Belakang Informasi

\begin{tabular}{|c|l|c|c|c|}
\hline No. & Indikator & Rata-rata & Persentasi & Kategori \\
\hline 1. & $\begin{array}{l}\text { Mahasiswa mampu mengenali jenis } \\
\text { informasi. }\end{array}$ & 4.20 & $84 \%$ & Sangat tinggi \\
\hline 2. & $\begin{array}{l}\text { Mahasiswa mampu mengenali sumber } \\
\text { informasi yang dibutuhkan. }\end{array}$ & 4.17 & $83.33 \%$ & Sangat tinggi \\
\hline 3. & $\begin{array}{l}\text { Mahasiswa mampu membedakan } \\
\text { sumber informasi yang valid dan tidak } \\
\text { valid. }\end{array}$ & 3.48 & $69.5 \%$ & Tinggi \\
\hline
\end{tabular}

Berdasarkan tabel 4 aspek pengetahuan mengenai latar belakang informasi diukur dengan menggunakan tiga indikator. Indikator pertama yaitu mahasiswa mahasiswa mampu mengenali jenis informasi memperoleh nilai rata-rata 4.20 dengan persentasi $84 \%$ dan berada pada kategori sangat tinggi. Selanjutnya, indikator kedua yaitu mahasiswa mampu mengenali sumber informasi yang dibutuhkan memperoleh nilai rata-rata 4.17 dengan persentasi $83.33 \%$ dengan kategori sangat tinggi. Indikator ketiga yaitu mahasiswa mampu membedakan sumber informasi yang valid dan tidak valid memperoleh nilai rata-rata 3.48 dengan persentase $69.5 \%$ dan berada pada kategori tinggi. Berdasarkan hasil penilaian tersebut, diperoleh kesimpulan bahwa tingkat literasi digital mahasiswa pada aspek pengetahuan mengenai latar belakang informasi untuk dua indikator berada pada kategori sangat tinggi dan satu indikator lainnya berada pada kategori tinggi. Hal ini berarti mahasiswa pada umumnya memiliki pengetahuan mengenai latar belakang informasi yang baik untuk mengkases berbagai jenis informasi yang dapat digunakan dalam pembelajaran menulis esai akademik.

Tabel 5. Aspek Pengetahuan Mengenai Latar Belakang Informasi

\begin{tabular}{|c|l|c|c|c|}
\hline No. & Indikator & Rata-rata & Persentasi & Kategori \\
\hline 1. & $\begin{array}{l}\text { Mahasiswa mampu menemukan konten } \\
\text { atau informasi yang dibutuhkan. }\end{array}$ & 4.43 & $88.6 \%$ & Sangat tinggi \\
\hline 2. & $\begin{array}{l}\text { Mahasiswa mampu menggunakan kata } \\
\text { kunci tertentu untuk menemukan } \\
\text { konten atau informasi yang dibutuhkan. }\end{array}$ & 4.44 & $88.7 \%$ & Sangat tinggi \\
\hline 3. & $\begin{array}{l}\text { Mahasiswa mampu menggunakan } \\
\text { sumber daya digital dalam penyelesaian } \\
\text { masalah. }\end{array}$ & 4.30 & $86.07 \%$ & Sangat tinggi \\
\hline
\end{tabular}




\begin{tabular}{|l|l|c|c|c|}
\hline 4. & $\begin{array}{l}\text { Mahasiswa mampu menilai dan } \\
\text { menganalisis sumber daya digital yang } \\
\text { diakses. }\end{array}$ & 3.63 & $72.50 \%$ & Tinggi \\
\hline 5. & $\begin{array}{l}\text { Mahasiswa mampu menyintesis sumber } \\
\text { daya digital yang diakses. }\end{array}$ & 3.94 & $78.80 \%$ & Tinggi \\
\hline 6. & $\begin{array}{l}\text { Mahasiswa mampu merefleksi hasil } \\
\text { yang telah diperoleh. }\end{array}$ & 3.94 & $78.80 \%$ & Tinggi \\
\hline 7. & $\begin{array}{l}\text { Mahasiswa mampu mengorganisasi, } \\
\text { mengintegrasikan, dan menghasilkan } \\
\text { informasi atau konten digital yang baru. }\end{array}$ & 4.16 & $83.13 \%$ & Sangat tinggi \\
\hline 8. & $\begin{array}{l}\text { Mahasiswa mampu mengomunikasikan } \\
\text { hasil kreasi melalui pranala (website) } \\
\text { edukasi. }\end{array}$ & 4.29 & $85.90 \%$ & Sangat tinggi \\
\hline 9. & $\begin{array}{l}\text { Mahasiswa mampu berkomunikasi, } \\
\text { berinteraksi, dan berkolaborasi melalui } \\
\text { pranala (website) edukasi. }\end{array}$ & 4.39 & $87.80 \%$ & Sangat tinggi \\
\hline
\end{tabular}

Berdasarkan tabel 5 aspek keterampilan utama literasi digital diukur dengan menggunakan sembilan indikator. Indikator pertama yaitu mahasiswa mampu menemukan konten atau informasi yang dibutuhkan memperoleh nilai rata-rata 4.43 dengan persentasi $88.6 \%$ dan berada pada kategori sangat tinggi. Selanjutnya, indikator kedua yaitu mahasiswa mampu menggunakan kata kunci tertentu untuk menemukan konten atau informasi yang dibutuhkan memperoleh nilai rata-rata 4.44 dengan persentasi $88.7 \%$ dengan kategori sangat tinggi. Indikator ketiga yaitu mahasiswa mampu menggunakan sumber daya digital dalam penyelesaian masalah memperoleh nilai rata-rata 4.30 dengan persentase $86.07 \%$ dan berada pada kategori tinggi. Indikator keempat yaitu mahasiswa mampu menilai dan menganalisis sumber daya digital yang diakses memperoleh nilai rata-rata 3.63 dengan persentasi $72.50 \%$ dan berada pada kategori tinggi. Indikator kelima yaitu mahasiswa mampu menyintesis sumber daya digital yang diakses memperoleh nilai rata-rata 3.94 dengan persentasi $78.80 \%$ dan berada pada kategori tinggi. Indikator keenam yaitu mahasiswa mampu merefleksi hasil yang telah diperoleh memperoleh nilai rata-rata 3.94 dengan persentasi $78.80 \%$ dan berada pada kategori tinggi. Indikator ketujuh yaitu mahasiswa mampu mengorganisasi, mengintegrasikan, dan menghasilkan informasi atau konten digital yang baru memperoleh nilai rata-rata 4.16 dengan persentasi $83.13 \%$ dan berada pada kategori sangat tinggi. Indikator kedelapan yaitu mahasiswa mampu mengomunikasikan hasil kreasi melalui pranala (website) edukasi memperoleh nilai rata-rata 4.29 dengan persentasi $85.90 \%$ dan berada pada kategori sangat tinggi. Indikator kesembilan yaitu mahasiswa mampu berkomunikasi, berinteraksi, dan berkolaborasi melalui pranala (website) edukasi memperoleh nilai rata-rata 4.39 dengan persentasi $87.80 \%$ dan berada pada kategori sangat tinggi.

Berdasarkan hasil penilaian tersebut, diperoleh kesimpulan bahwa tingkat literasi digital mahasiswa pada aspek keterampilan utama, terdapat enam indikator berada pada kategori sangat tinggi dan tiga indikator berada pada kategori tinggi. Hal ini berarti mahasiswa pada umumnya memiliki keterampilan utama yang baik untuk menggunakan dan mengakses berbagai sumber daya digital untuk digunakan dalam pembelajaran menulis esai akademik. 
Tabel 6. Aspek Sikap dan Perspektif

\begin{tabular}{|c|l|c|c|c|}
\hline No. & Indikator & Rata-rata & Persentasi & Kategori \\
\hline 1. & $\begin{array}{l}\text { Mahasiswa mampu mengakses dan } \\
\text { menilai konten digital secara mandiri. }\end{array}$ & 4.04 & $81 \%$ & Sangat tinggi \\
\hline 2. & $\begin{array}{l}\text { Mahasiswa mampu bertanggung jawab } \\
\text { terhadap informasi atau konten digital } \\
\text { yang disebarkan. }\end{array}$ & 4.01 & $80 \%$ & Tinggi \\
\hline
\end{tabular}

Berdasarkan tabel di atas, aspek sikpa dan perspektif pada literasi digital mahasiswa diukur dengan menggunakan dua indikator. Indikator pertama yaitu mahasiswa mampu mengakses dan menilai konten digital secara mandiri memperoleh nilai rata-rata 4.04 dengan persentasi $81 \%$ dan berada pada kategori sangat tinggi. Selanjutnya, indikator kedua yaitu mahasiswa mampu bertanggung jawab terhadap informasi atau konten digital yang disebarkan memperoleh nilai rata-rata 4.01 dengan persentasi $80 \%$ dan pada kategori tinggi. Berdasarkan hasil penilaian tersebut, diperoleh kesimpulan bahwa tingkat literasi digital mahasiswa pada aspek sikap dan perspektif, satu indikator berada pada kategori sangat tinggi dan satu indikator lainnya berada pada kategori tinggi. Hal ini berarti mahasiswa pada umumnya memiliki sikap dan perspektif yang baik untuk menggunakan keterampilan literasi digitalnya daam pembelajaran menulis esai akademik.
Keandalan Sumber Referensi Mahasiswa

Keandalan sumber dapat dilihat dari sumber referensi yang digunakan oleh mahasiswa dalam tulisan esai akademiknya. Keandalan sumber ini terkait dengan asalusul sumber referensi yang digunakan. Asal sumber referensi yang diperiksa yaitu sumber yang diperoleh dari internet. Hal ini dilakukan untuk melihat sejauh mana siswa mengenali sumber-sumber referensi yang valid yang berasal dari internet.

Dari hasil penelusuran pada tulisan esai akademik mahasiswa, terdapat empat sumber referensi daring yang digunakan. Sumber referensi tersebut diperoleh dari artikel jurnal daring, situs web institusi akademik (.ac.id), situs web institusi pemerintahan (.go.id), dan blogspot.com. Darihasil pemeriksaan terhadap dokumen esai akademik mahasiswa yang terdiri atas 32 orang, diperoleh data sebagai berikut.

Tabel 7. Persentase Penggunaan Sumber Referensi Online.

\begin{tabular}{|l|l|c|c|}
\hline No. & Referensi & Jumlah & Persentasi \\
\hline 1. & Jurnal daring & 32 & $100 \%$ \\
2. & Situs web institusi akademik (.ac.id) & 18 & $56.25 \%$ \\
3. & Situs web pemerintah (.go.id) & 21 & $65.63 \%$ \\
4. & Blogspot.com & 7 & $21.88 \%$ \\
\hline
\end{tabular}

Berdasarkan hasil yang tertera pada tabel di atas, diperoleh bahwa semua mahasiswa atau 32 (100\%) menggunakan artikel jurnal daring sebagai referensi esai akademinya. Situs web institusi akademik dipilih oleh $18(56.25 \%)$ orang mahasiswa sebagai referensi, dan sebanyak 21 (65.63\%) memilih situs web pemerintah (.go.id). Sedangkan, untuk referensi yang berasal dari blogspot.com dipilih oleh 7 (21.88\%) orang mahasiswa untuk dicantumkan dalam esai akaemiknya.

Pada studi ini, peneliti berusaha mengungkap kemampuan tingkat literasi digital mahasiswa dan kemampuan memilih sumber referensi untuk digunakan dalam menulis esai akademik. Studi ini melibatkan 32 mahasiswa yang mengikuti pembelajaran menulis esai akademik. Mahasiswa mengikuti pembelajaran daring melalui penggunaan LMS yang dikembangkan oleh 
pihak kampus. Materi pembelajaran yang diberikan yaitu esai akademik dan penggunaan referensi. Selain itu, mahasiswa juga diberikan pelatihan untuk menggunakan aplikasi manajemen referensi, untuk menghindari plagiasi tulisan. Selanjutnya, mahasiswa diberikan tes menulis esai akademik.

Hasil yang diperoleh dari angket tingkat literasi digital yang terdiri dari empat aspek yaitu aspek kompetensi digital, pengetahuan mengenai latar belakang informasi, kompetensi utama, serta sikap dan perspektif menunjukkan bahwa pada umumnya mahasiswa memiliki tingkat literasi digital yang sangat tinggi dan tinggi.

Aspek kompetensi digital mahasiswa berada pada kategori sangat tinggi. Hal ini berarti mahasiswa memiliki kompetensi atau pengetahuan mengenai penggunaan berbagai teknologi dan aplikasi-aplikasi yang digunakan dalam proses pembelajaran. Kompetensi digital memperluas peluang bagi mahasiswa untuk terlibat aktif dalam mode pembelajaran yang memanfaatkan berbagai teknologi digital seperti komputer, smartphone, tablet, jaringan dan platform media sosial, dll (Huda et al., 2017). Selain itu, pemanfaatan konten-konten digital oleh mahasiswa harus didukung oleh kompetensi penggunaan alat-alat digital dalam mengakses informasi, kompetensi untuk memilah informasi yang tidak berurutan (nonsequential), kompetensi berpikir kritis dalam menelaah informasi yang diperoleh, dan kompetensi mengomunikasikan tulisan yang dihasilkan (Haliq \& Riyanti, 2018).

Adapun media teknologi yang digunakan mahasiswa dalam pembelajaran daring ini yaitu laptop dan handphone. Untuk kelas virtual digunakan LMS yang dikembangkan oleh institusi UNM dan beberapa aplikasi untuk mendukung pembelajaran seperti aplikasi manajemen referensi Zotero, mesin pencari (Google), dan video pembelajaran. Kompetensi digital ini pada dasarnya menjadi prasyarat untuk terlibat aktif dalam pembelajaran berbasis digital di perguruan tinggi (Chan et al., 2017; López-Meneses et al., 2020).

Aspek yang kedua yang kedua dalam literasi digital yaitu pengetahuan mengenai latar belakang informasi. Berdasarkan hasil pengukuran, diperoleh kesimpulan bahwa mahasiswa memiliki pengetahuan mengenai latar belakang informasi yang baik untuk mengkases berbagai jenis informasi yang dapat digunakan dalam pembelajaran menulis esai akademik. Pengetahuan megenai informasi atau sumber-sumber bahan pembelajaran online, dapat membantu proses belajar sehingga bahan dan sumber belajar dapat lebih bervariatif. Hal ini penting dilakukan dalam kegiatan pembelajaran dan dilakukan dengan menyediakan berbagai tautan sumber belajar, video pembelajaran, serta tulisan/bahan bacaan e-book (Mahande et al., 2021) yang sesuai dengan tujuan pembelajaran menulis esai akademik. Pengetahuan mengenai sumber-sumber yang kredibel juga diperlukan agar mahasiswa tidak menggunakan sumber-sumber referensi yang tidak valid.

Aspek ketiga dalam literasi digital yaitu keterampilan utama. Berdasarkan hasil angket yang diperoleh dari 32 mahasiswa, dapat disimpulkan bahwa mahasiswa pada umumnya memiliki keterampilan utama yang baik untuk menggunakan dan mengakses berbagai sumber daya digital untuk digunakan dalam pembelajaran menulis esai akademik. Aspek keterampilan utama ini merupakan keterampilan yang paling penting untuk melakukan aksi-aksi digital dalam menggunakan dan memperoleh berbagai sumber daya digital yang dapat dimanfaatkan dalam pembelajaran menulis esai akademik. Dalam praktik literasi digital dalam pembelajaran, mahasiswa didorong untuk mengidentifikasi, mengakses, mengevaluasi, menginterpretasi, meng-organisasi, mengintegrasi, menganalisis, menyintesis, mengkreasi, mengo-munikasikan, mendiseminasi, dan merefleksi konten-konten digital (Martin \& Grudziecki, 2006). Kegiatan ini menunjukkan bahwa mahasiswa harus mampu mengevaluasi secara kritis sumbersumber belajar atau referensi yang akan digunakan (Bawden, 2008; Spires et al., 2018) serta secara kreatif mampu menghasilkan konten digital baru dan berimplikasi positif bagi warganet (LópezMeneses et al., 2020). 
Aspek keempat dalam literasi digital yaitu sikap dan perspektif. Berdasarkan hasil penelitian, diperoleh bahwa mahasiswa pada umumnya memiliki sikap dan perspektif yang baik untuk menggunakan keterampilan literasi digitalnya dalam pembelajaran menulis esai akademik. Mahasiswa mampu memilih dan menilai sumber daya digital yang dapat digunakan dalam pembelajaran menulis esai akademik. Sumber daya digital yang diperoleh merupakan sumber daya yang kredibel dan sesuai dengan kebutuhan pembelajaran. Selain itu, mahasiswa juga mampu menyebarkan konten-konten digital yang baik dan valid untuk dikonsumsi oleh warganet.

Tingkat literasi digital yang sangat tinggi pada mahasiswa berimbas pada kemampuan mahasiswa memilih sumbersumber referensi yang digunakan dalam menulis esai akademik. Hal ini terlihat pada dokumen tulisan esai akademik mahasiswa yang pada umumnya menggunakan referensi kredibe seperti jurnal online, informasi yang berasal dari situs web institusi akademik (.ac.id) dan pemerintahan (.go.id). Sumbersumber referensi ini merupakan sumber yang kredibel karena dikelola secara professional dan informasi yang berada dalam situs web tersebut telah tervalidasi. Hal inilah yang menjadi alasan mahasiswa sehingga menggunakan sumber referensi oline tersebut. Penggunaan jurnal online mendominasi dalam referensi esai akademik mahasiswa. Hal ini cukup beralasan karena jurnal online merupakan sumber referensi yang valid dan terpercaya. Hal yang sama juga dikemukakan oleh Rose-Wiles \& Marzabadi, (2018) bahwa penggunaan jurnal ilmiah sebagai referensi meningkat dari waktu ke waktu karena jurnal ilmiah merupakan tempat publikasi artikel-artikel ilmiah.

Selain itu, mahasiswa juga mampu menggunakan aplikasi manajemen referensi Zotero dengan baik untuk mengelola referensi esai akademik. Hal ini terlihat dari penulisan referensi yang baik dan sesuai gaya selingkung yang disepakati dan melakukan sitasi terhadap artikel-artikel ilmiah. Seperti yang dikemukakan Haliq et al., (2021) pemanfaatan aplikasi Zotero memudahkan mahasiswa mengelola referensi, memiliki perpustakaan digital, dan kemudahan sitasi tulisan.

Selanjutnya, terdapat beberapa esai akademik yang menggunakan sumber referensi berupa informasi yang diperoleh dari blogspot.com. Mahasiswa beralasan, bahwa beberapa blogspot tersebut diisi oleh tulisan-tulisan ilmiah seperti makalah atau artikel. Selain itu, beberapa blogspot juga dikelola oleh akademisi seperti dosen. Alasan ini yang membuat mahasiswa mengambil sumber referensi blogspot.com sebagai referensi untuk penulisan esai akademiknya. Penggunaan Blogspot.com sebagai sumber referensi untuk tulisan ilmiah pada dasarnya tidak disarankan. Sebagai referensi tulisan ilmiah, Blog merupakan referensi yang tidak dapat diandalkan (Pretorius, 2018) karena Blog merupakan website pribadi yang publikasinya tidak terkonfirmasi oleh ahli.

\section{SIMPULAN}

Peneilitian ini mendeskripsikan tingkat literasi digital mahasiswa dan keandalan sumber referensi esai akademik. Pertama, hasil penelitian ini menunjukkan bahwa tingkat literasi digital mahasiswa pada umumnya berada pada kategori sangat tinggi dan tinggi. Hal ini berarti mahasiswa memiliki keterampilan literasi digital yang sangat baik untuk digunakan dalam pembelajaran menulis esai akademik secara daring dengan penggunaan berbagai perangkat teknologi dan aplikasi-aplikasi pembelajaran.

Kedua, sumber referensi tulisan esai akademik mahasiswa pada umumnya berasal dari sumber yang kredibel dan terpercaya. Hal ini dapat dilihat pada tulisan esai akademik mahasiswa yang menggunakan sumber referensi seperti jurnal online dan situs web institusi Pendidikan dan pemerintahan. Terdapat beberapa esai yang menggunakan blog pribadi sebagai sumber referensi, namun tulisan yang berada dalam blog pribadi tersebut dapat dikonfirmasi sebagai tulisan ilmiah.

Akhirnya, hal yang terpenting dalam penelitian ini adalah bagaimana mahasiswa memanfaatkan keterampilan literasi digital selama pembelajaran daring diberlakukan pada masa pandemi Covid 19. Keterampilan 
literasi digital sangat dibutuhkan untuk menggunakan berbagai perangkat digital dan aksi-aksi digital mahasiswa dalam memperoleh sumber daya digital yang dapat dimanfaatkan dalam pembelajaran daring.

\section{DAFTAR PUSTAKA}

Bawden, D. (2008). Origins and concepts of digital literacy. In Digital literacy and participation in online social networking spaces (pp. 17-32).

Buwono, S., \& Dewantara, J. A. (2020). Hubungan Media Internet, Membaca, Dan Menulis Dalam Literasi Digital Mahasiswa. Jurnal Basicedu, 4(4), 1186-1193.

Chan, B. S. K., Churchill, D., \& Chiu, T. K. F. (2017). Digital literacy learning in higher education through digital storytelling approach. Journal of International Education Research (JIER), 13(1), 1-16.

Hafner, C. A., Chik, A., \& Jones, R. H. (2015). Digital literacies and language learning. Language Learning \& Technology, 19(3), 1-7.

Haliq, A., Hamsa, A., \& Sakaria, S. (2021). Analisis pemanfaatan, faktor pendukung dan penghambat, serta upaya optimalisasi aplikasi zotero dalam penulisan karya ilmiah. Edukasi: Jurnal Pendidikan, 19(1), 16.

Haliq, A., \& Riyanti, A. (2018). Pembelajaran mandiri melalui literasi digital. Bahasa Di Era Digital: Peluang Atau Ancaman?, 1-6.

Huda, M., Jasmi, K. A., Hehsan, A., Mustari, M. I., Shahrill, M., Basiron, B., \& Gassama, S. K. (2017). Empowering children with adaptive technology skills: careful engagement in the digital information age. 16.

Irhandayaningsih, A. (2020). Pengukuran literasi digital pada peserta pembelajaran daring di masa pandemi COVID-19. ANUVA, 4(2), 231-240.

Kirschner, P. A., \& De Bruyckere, P. (2017). The myths of the digital native and the multitasker. Teaching and Teacher Education, 67, 135-142.

López-Meneses, E., Sirignano, F. M., Vázquez-Cano, E., \& Ramírez-
Hurtado, J. M. (2020). University students' digital competence in three areas of the DigCom 2.1 model: A comparative study at three European universities. Australasian Journal of Educational Technology, 69-88.

Mahande, R. D., Malago, J. D., \& Hartoto. (2021). The Prototype of 4CS-Based blended learning content. Journal of Educators Online, 18(1). https://www.thejeo.com/archive/archi ve/2021_181/mahande_malago_hart otopdf

Martin, A., \& Grudziecki, J. (2006). DigEuLit: concepts and tools for digital literacy development. Innovation in Teaching and Learning in Information and Computer Sciences, 5(4), 249-267.

Pretorius, L. (2018). Experiential and selfdiscovery learning in digital literacy: Developing the discernment to evaluate source reliability. College \& Undergraduate Libraries, 25(4), 388405.

Riduwan. (2008). Belajar mudah penelitian untuk guru, karyawan dan peneliti pemula. Alfabeta.

Rose-Wiles, L., \& Marzabadi, C. (2018). Chemistry reference data 2018 [Data set]. Mendeley.

Spires, H. A., Paul, C. M., \& Kerkhoff, S. N. (2018). Digital literacy for the 21st century. In Encyclopedia of information science and technology. (4th ed.). IGI Global.

Supriyanto, W., \& Iswandari, R. (2017). Kecenderungan sivitas akademika dalam memilih sumber referensi untuk penyusunan karya tulis ilmiah di perguruan tinggi. Berkala Ilmu Perpustakaan dan Informasi, 13(1), 79. 